\title{
Cultural responses to the migration of the barn swallow in Europe
}

\section{Ashleigh Green}

University of Melbourne

Abstract: This paper investigates the place of barn swallows in European folklore and science from the Bronze Age to the nineteenth century. It takes the swallow's natural migratory patterns as a starting point, and investigates how different cultural groups across this period have responded to the bird's departure in autumn and its subsequent return every spring. While my analysis is focused on classical European texts, including scientific and theological writings, I have also considered the swallow's representation in art. The aim of this article is to build a longue durée account of how beliefs about the swallow have evolved over time, even as the bird's migratory patterns have remained the same. As I argue, the influence of classical texts on medieval and Renaissance thought in Europe allows us to consider a temporal progression (and sometimes regression) in the way barn swallow migration was explained and understood.

\section{The barn swallow}

The barn swallow (Hirundo rustica) has two defining characteristics that have shaped how people living in Europe have responded to its presence over the centuries. The first relates to its movement across continents. The swallow migrates to Africa every autumn and returns to Asia in spring for breeding. Second, it is a bird that is often found in urban environments, typically nesting in or on buildings to rear its young. ${ }^{1}$ These two characteristics have meant that the barn swallow has been a feature of European life for centuries and has prompted a myriad of responses in science and folklore-particularly in Greek mythology. Yet, although the

1 Stanley Cramp (ed.), Handbook of the Birds of Europe, the Middle East and North Africa: The Birds of the Western Palearctic, vol. 5 (Oxford \& New York: Oxford University Press, 1988), $263 \mathrm{ff}$. 
barn swallow is well known for its appearance in the Greek myth of Procne and Philomela, this article only gives the myth cursory attention, focusing instead on how different European societies have attempted to explain the barn swallow's migration, rather than how they have mythologised it.

Before we continue, it is important to acknowledge that accounts of the barn swallow overlap with several species that are similar in appearance and behaviour. In Greek, the swallow was called chelidon ( $\chi \varepsilon \lambda 1 \delta \omega \dot{v})$, and in Latin, it was hirundo. These words generally referred to the barn swallow, but they were also used to refer to the house martin (Delichon urbica), red-rumped swallow ( $H$. daurica), sand martin (Riparia riparia) and crag martin (Ptyonoprogne rupestris). ${ }^{2}$ The swift (Apus apus), though not a part of the swallow family, is somewhat similar in appearance and might also be confused with the swallow when seen in flight.

Pliny the Elder (25-79 CE) is the only ancient Roman author who makes an attempt to distinguish between different types of hirundo, noting the differences between the barn swallow, house martin and sand martin on the basis of the nests they build. ${ }^{3}$ All these birds have a similar silhouette, typified by streamlined wings and a forked tail, but the barn swallow is distinguished by its bright red chin patch and more deeply forked tail. The house martin is the bird that is most likely to be confused with swallow, being most similar in appearance and also living in close proximity to people. However, at least among the ancients, the barn swallow appears to have been more keenly observed, for while there are many fine examples of the barn swallow in ancient art, there do not appear to be any of the house martin. Nevertheless, since the house martin and other hirundines share the swallow's migratory patterns, which are the focus of this study, I want to suggest that confusion between these species among contemporaries does not necessarily pose an insurmountable problem. While it might not always be possible to determine whether a barn swallow is indeed a barn swallow, if migration and cohabitation are attributed to the bird(s) being described, similar conclusions can be drawn.

2 W Geoffrey Arnott, Birds in the Ancient World from A to $Z$ (London \& New York: Routledge, 2007), 47: doi.org/10.4324/9780203946626.

3 Pliny, Natural History, 10.92-94, cited in H Rackham, Natural History, Volume III: Books 8-11, Loeb Classical Library 353 (Cambridge: Harvard University Press, 1940). 
One further point that is important to note is that swallows and martins are insectivores, meaning they are harmless to food stores and therefore generally tolerated when they choose to nest in homes or public buildings. The eighteenth-century naturalist Gilbert White perhaps gives us the best introductory snapshot:

The Hirundines are a most inoffensive, harmless, entertaining, social and useful tribe of birds; they touch no fruit in our gardens; delight, all except one species, in attaching themselves to our houses; amuse us with their migrations, songs, and marvellous agility; and clear our outlets from the annoyances of gnats and other troublesome insects. ${ }^{4}$

With this, we can now begin to chart some of the different cultural responses to the barn swallow's behaviour, beginning with the ancient world.

\section{Swallows in the Ancient Mediterranean}

In Europe, the swallow has been greeted as spring's herald since time immemorial. Zooarchaeologist Dale Serjeantsen notes that Palaeolithic people would have watched for swallows and martins as a sign of spring and even shared caves with nesting parents. ${ }^{5}$ At the Minoan site of Akrotiri, which was devastated by the Thera eruption in the mid-second millennium BCE, the Minoan 'Spring Fresco' (c. 1600 BCE) features blooming lilies and dancing swallows. ${ }^{6}$ Hesiod (c. 700 BCE) believed that swallows proclaimed spring. ${ }^{7}$ Latin poets spoke of the 'stranger swallow' coming to announce springtime while the agricultural writer Columella (4-70 CE) advises farmers to prepare for spring planting when the

4 Gilbert White, cited in Eric Hosking and Cyril Newberry, The Swallow (London: Collins, 1946), 11.

5 Dale Serjeantsen, Birds (Cambridge: Cambridge University Press, 2009), 1.

6 Mary B Hollinshead, 'The Swallows and Artists of Room Delta 2 at Akrotiri, Thera', American Journal of Archaeology 93, no. 3 (July 1989), 339-54: doi.org/10.2307/505585. It was initially believed the swallows were displaying courtship behaviour, but according to Hollinshead it depicts adults feeding juveniles on the wing. On fighting males, see Karen Polinger Foster, 'A Flight of Swallows', American Journal of Archaeology 99, no. 3 (July 1995), 409-25: doi.org/10.2307/506942.

7 Hesiod, Works and Days, 568, cited in Glenn W Most, Theogony. Works and Days. Testimonia, Loeb Classical Library 57 (Cambridge: Harvard University Press, 2007). See also Aristophanes, Birds, 714-15, cited in Jeffrey Henderson, Birds. Lysistrata. Women at the Thesmophoria, Loeb Classical Library 179 (Cambridge: Harvard University Press, 2000). 
swallows return. ${ }^{8}$ The people of Rhodes particularly loved the swallow; you were considered lucky if a swallow nested in your house. Athenaeus of Naucratis, writing in the third century CE and quoting older literary works, records that after the first swallow was spotted the Rhodians would hold a festival and the children would sing:

He comes! He comes! Who loves to hear

Soft sunny hours, and seasons fair:

The swallow hither comes to rest

His sable wing and snowy breast. ${ }^{9}$

The children then ran to different houses and 'played the chelidon', demanding residents open their doors and give them food-rather like modern trick-or-treaters during Halloween. ${ }^{10}$ It is no coincidence that the swallow-loving Rhodians made charming perfume bottles in the shape of swallows (Figures 1 and 2).



Figure 1: Terracotta scent bottle found in Kameiros, Rhodian, c. 610550 BCE.

Source: British Museum, 1860,0404.32.

8 Horace, Epistles, 1.7.12-13, cited in H Rushton Fairclough, Satires. Epistles. The Art of Poetry, Loeb Classical Library 194 (Cambridge: Harvard University Press, 1926); Ovid, Fasti, 1.157-158 \& 2.853856, cited in James G Frazer, Fasti, Loeb Classical Library 253 (Cambridge: Harvard University Press, 1931); Columella, On Farming, 11.2.21 \& 10.80; ES Forster and Edward H Heffner, On Agriculture, Volume III: Books 10-12. On Trees, Loeb Classical Library 408 (Cambridge: Harvard University Press, 1955). See also Aelian, On the Nature of Animals, 1.52, cited in AF Scholfield, On Animals, Volume I: Books 1-5, Loeb Classical Library 446 (Cambridge: Harvard University Press, 1958).

9 Athenaeus, The Intellectuals' Dinner Party, 360c-d, translation from Charles Swainson, Provincial Names and Folk Lore of British Birds (London: Trübner \& Co, 1885), 50.

10 Arnott, Birds, 47. 


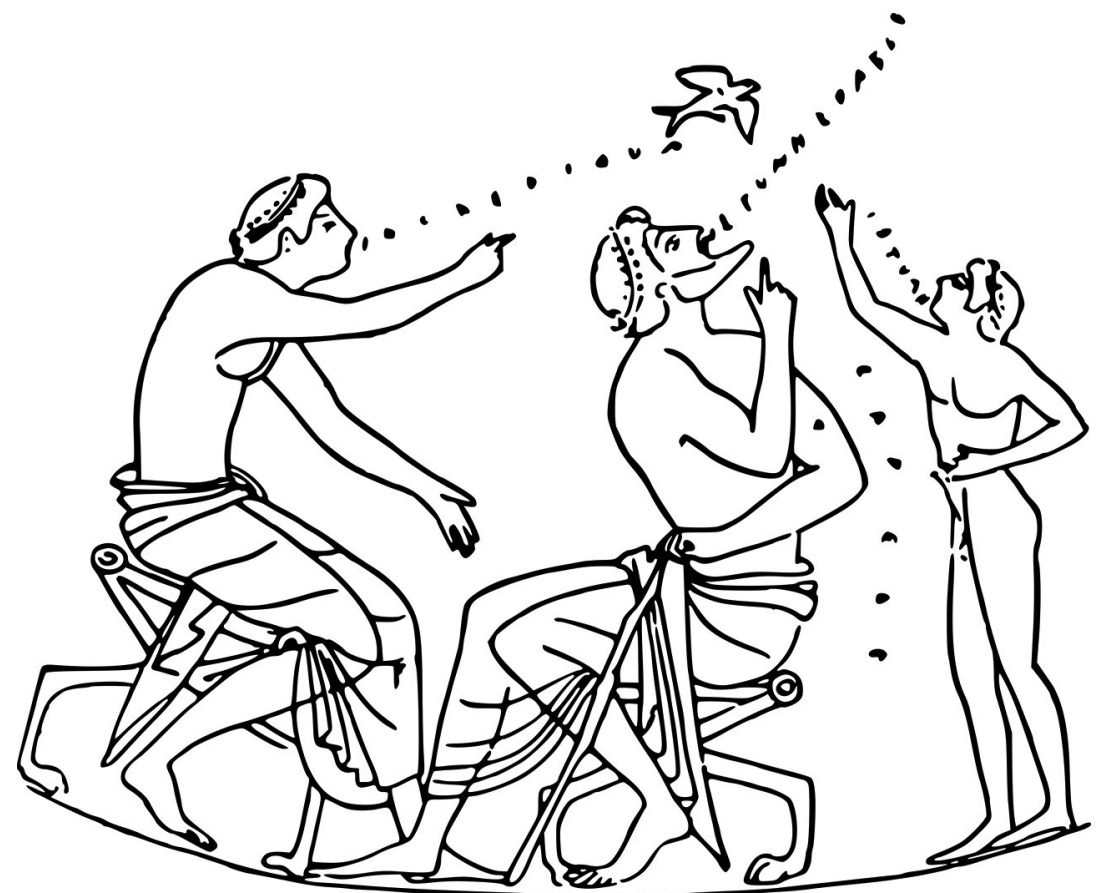

Figure 2: The First Swallow of Spring.

Source: Illustration from S Reinach, Rèpertoire des vases peints (Paris, 1899).

Another ancient representation comes from an Attic red figure vase (c. $510 \mathrm{BCE}$ ), where three men look at a swallow and cheer, 'Look, a swallow [...] it must be spring!' (Figure 3). Aristophanes gives a comedic parody of this sentiment when a character uses the same cheer to distract a cook in order to steal some meat, an account that indicates it was routine to announce the swallow's return when it was first spotted. ${ }^{11}$

The Roman writer Varro (116-27 BCE) observes that when the swallow returns he nests in tecto-literally, 'under the roof'. ${ }^{12}$ This is an oft-repeated idea, and is usually translated as 'under the eaves', a mistaken interpretation as the Roman word for 'eave' is suggrunda, while tectum is roof. There is a very good chance that when the ancients, both Greek and Roman, say the birds nested under their roofs they really do mean inside their houses, and not on the outer walls. As the early Scottish anthropologist

11 Aristophanes, Knights, 417-20, cited in Jeffrey Henderson, Acharnians. Knights, Loeb Classical Library 178 (Cambridge: Harvard University Press, 1998).

12 Varro, On Agriculture, 3.5.7, cited in WD Hooper and Harrison Boyd Ash, On Agriculture, Loeb Classical Library 283 (Cambridge: Harvard University Press, 1934). 
James George Frazer explains, Greek houses would not have had glass in their windows, only shutters that were closed at night and open during the day. The roof beams were usually exposed so swallows and house martins could easily have entered through the windows and nested on the wooden beams. Since the shutters were closed at night, the swallows would have roused the household at first light by twittering impatiently to get out. ${ }^{13}$ Indeed, descriptions of swallows twittering around the heads of slumbering men and women at dawn are symbolic. ${ }^{14}$

Such behaviour also explains why the Roman author Aelian (175-235 CE) says that the birds share a house with men, and why men in turn were expected to extend Homer's laws of hospitality to the swallow-that is, befriend the guest who shares your table and send him on his way when he wants to go. ${ }^{15}$ In the same vein, Pliny notes that swallows are paradoxically wild and domestic at the same time. ${ }^{16}$ Untamed, yet living in homes, they were sacred to household gods and under their protection. ${ }^{17}$ The poet Ovid (43 BCE-18 CE) suggests that people generally avoided harming the bird because he is gentle. ${ }^{18}$

In Roman art of the early Empire, particularly in the Campanian region from $0-100 \mathrm{CE}$, there is a movement away from the traditional depiction of a swallow in flight towards a more homely, rustic image where it is perched around the house. ${ }^{19}$ On one villa wall painting a swallow is shown perched next to a sparrow in the role of domestic familiar. ${ }^{20}$ Other descriptions show how closely people watched the swallow: their skill at

13 James Frazer, 'Swallows in the House', The Classical Review 5, no. 1/2 (February 1891), 1-3: doi.org/10.1017/S0009840X00992990.

14 Greek Anthology, vol. 237, cited in WR Paton and Michael A Tueller, Greek Anthology, Volume I, Loeb Classical Library 67 (Cambridge: Harvard University Press, 2014). This text was written by Agathius Scholasticus in the mid-sixth century and it complains of swallows waking the poet from a pleasant sex dream at dawn. See also Aelian, On the Nature of Animals, 9.17.

15 Aelian, On the Nature of Animals, 1.52; Homer, Odyssey 15.72-74, cited in AT Murrary, Odyssey, Volume II: Books 13-24, Loeb Classical Library 105 (Cambridge: Harvard University Press, 1919).

16 Pliny, Natural History, 8.82.

17 Aelian, On the Nature of Animals, 10.34.

18 Aelian, On the Nature of Animals, 1.58; Ovid, Ars Amatoria, 2.149-150, cited in JH Mozley and GP Goold, Art of Love. Cosmetics. Remedies for Love. Ibis. Walnut-tree. Sea Fishing. Consolation, Loeb Classical Library 232 (Cambridge: Harvard University Press, 1929). In Latin, mitis is translated to mean mild, meek or gentle.

19 Arnott, Birds, 48.

20 Jeremy Mynott, Birds in the Ancient World (Oxford: Oxford University Press, 2018), illustration 3.11 . 
building nests was prodigious. ${ }^{21}$ In one legend, Pliny notes that when men dwelled in caves they learned the art of brick and clay-making from watching swallows. ${ }^{22}$ The swallow was also said to be a diligent parent, feeding their chicks even after they had flown from the nest-no doubt an observation of parents caring for chicks within the house, and watching them feed their fledged chicks while flying. ${ }^{23}$

The role of the swallow as an announcer of spring was central to stories of the bird. In ancient times, people did not rely on calendars or clocks to tell them the time or the passing of the seasons. They watched and listened to birds. Cockcrow heralded sunrise and roused them from sleep; cranes migrating told them it was time to sow; and swallows returning from worlds unknown told them spring had arrived. ${ }^{24}$ The sailing season was also marked by the swallow's return. Taking the swallow's appearance as their cue, centuries of Greek poets sang to sailors to weigh anchor and unfurl the sails. They repeat the same imagery: the swallows are here and the zephyrs are blowing. Winter storms have passed, and it is time to go to sea. ${ }^{25}$ The spring wind was even called chelidonia after the swallow, ${ }^{26}$ and Horace suggests that the swallow actually helps to calm the sea. ${ }^{27}$

The concept of migration - that birds travelled to live in more favourable climates when the weather changed-was not always fully understood. In ancient writings, there is considerable emphasis on greeting the swallow in spring and watching for its departure, but knowledge about where it went and why is less well considered. The Greeks and Romans appear to have understood the swallow's migratory movements to some degree, which might explain why the swallow was often associated with the sea.

21 Aelian, On the Nature of Animals, 3.24; Aristotle, History of Animals, 612 23b, cited in DM Balme, History of Animals, Volume III: Books 7-10, Loeb Classical Library 439 (Cambridge: Harvard University Press, 1991).

22 Pliny, Natural History, 7.61.

23 Aelian, On the Nature of Animals, 3.25; Pliny, Natural History, $10.14 \& 10.49$.

24 Eugene S McCartney, 'The Folk Calendar of Times and Seasons', The Classical Weekly 16, no. 1 (October 1922), 3-7: doi.org/10.2307/4388369.

25 Greek Anthology, X.1, 2, 4, 5, 14, cited in WR Paton, The Greek Anthology, Volume IV: Book 10: The Hortatory and Admonitory Epigrams. Book 11: The Convivial and Satirical Epigrams. Book 12: Strato's Musa Puerilis, Loeb Classical Library 85 (Cambridge: Harvard University Press, 1918). These poems are written by Leonidas, Antipater of Sidon, Marcus Argentarius, Thyillus and Agathias Scholasticus respectively, and although they stretch from the third century BCE to the sixth century CE, they are almost identical in form and substance. Such evidence suggests that swallows truly were linked as closely to sailing as to spring.

26 Mynott, Birds, $1 \mathrm{ff}$.

27 Horace, Odes, 4.12.1-6. 
As land birds, swallows prefer to migrate overland as much as possible, but they are capable of crossing considerable bodies of water such as the English Channel and the Mediterranean Sea. ${ }^{28}$

In his hugely influential zoological work History of Animals, Aristotle (fourth century BCE) explains that some swallows migrate, retiring to nearby warmer environments, while others hibernate during the winter and moult their feathers in their dormant state. Following in Aristotle's footsteps, Pliny notes that only some swallows-not all-migrate, while Varro acknowledges that swallows and a number of other birds migrate across the sea by island hopping. ${ }^{29}$ Herodotus, hailed as the father of history, recorded in the fifth century BCE that swallows could live year-round in the lands that the Nile passes through. ${ }^{30}$ The annual disappearance of other birds was explained in less plausible ways (such as transmutation), but, despite the confusion, it was generally agreed that the swallow departed to somewhere. This allowed the bird to be understood as a traveller returning home or a sailor returning from sea, completing his voyage to enjoy a long sojourn with his family. Thus, in the Odyssey, when weary Odysseus finally returns home and strings his beloved bow, it sings like a swallow. The bowstring's unusual call here should be understood as heralding the hero's return, for Odysseus, like the swallow, has returned from across the sea to his matrimonial nest. ${ }^{31}$

The swallow's arrival in spring brought joy, but its departure in autumn signalled imminent hardship. Unsurprisingly, omens connected to the swallow could be similarly fortunate or dire. ${ }^{32}$ Most famously there is the Greek legend of the sisters Philomela and Procne, which depicts Philomela, who is violently raped by her sister's husband, transforming into a swallow, while Procne, who murders her own son to exact revenge on her husband for his cruelty against her sister, transforms into

28 Karen Edwards, 'Milton's Reformed Animals: An Early Modern Bestiary: S', Milton Quarterly 43, no. 2 (May 2009), 130; Cramp et al., Handbook of Birds, 263.

29 Aristotle, History of Animals, 8.16.600A16; Pliny, Natural History, 10.70; Varro, On Farming, 3.5.7.

30 Herodotus, The Persian Wars, 2.22, cited in AD Goodley, The Persian Wars, Volume I: Books 1-2, Loeb Classical Library 117 (Cambridge: Harvard University Press, 1920).

31 Homer, Odyssey, 21.410. See also L Losada, 'Odyssey 21.411: The Swallow's Call', Classical Philology 80, no. 1 (January 1985), 34: doi.org/10.1086/366895; E Borthwick, 'Odysseus and the Return of the Swallow', Greece and Rome 35, no. 1 (April 1988), 14-15: doi.org/10.1017/S0017383500028722. The swallow's twitter was more commonly compared to barbarous, unintelligible speech in Greek literature. See Aeschylus, Agamemnon, 1050-51 and Aristophanes, Frogs, 678-82.

32 Beryl Rowland, Birds with Human Souls: A Guide to Bird Symbolism (Knoxville: University of Tennessee Press, 1978), 165. 
a nightingale. As a result, attitudes towards the birds were often tinged with the myth's sadness. ${ }^{33}$ Some tellings of the legends by the Romans made Procne the swallow and Philomela the nightingale, proclaiming the red breast of the swallow as a stain of blood, a symbol of how Procne's sin in murdering her son Itys could never be washed clean. ${ }^{34}$

Yet, the swallow's status as a bird of ill omen remained ambiguous and the ancients never comfortably reconciled the legend of Philomela and Procne with natural observation. In Interpretation of Dreams (second century $\mathrm{CE}$ ), the diviner Artemidorus writes that the swallow can foreshadow death and great sadness, likely a result of its connection with the tragic myth. He also adds that this is only the case when something bad happens to the swallow-for example, if it changes colour or does something contrary to its nature. He goes on to say that the swallow is hidden and inactive during winter, just like the earth and the sea-but when spring comes, the swallow is the first to rouse men and women to life, love and work. Swallows twitter at dawn, reminding their housemates daily of their duties. As an omen, the swallow is most fortunate for business, music and, above all, marriage. ${ }^{35}$

Other omens we see are commonly related to journeys and enterprises. Swallows made their nest on the tent of Alexander of Epirus, the son of Pyrrhus (crowned 272 BCE), foretelling that his enterprise would fail. Central to this tale is the fact that the tent was a temporary structurewhen Alexander departed, it would have forced him to dislodge the birds, making their misfortune his own. Swallows made their nests in the tent of Antiochus VII, King of Syria, who died trying to restore the realm of his forefathers in $129 \mathrm{BCE}$. Swallows also foretold the return of Dionysius the Elder, tyrant of Syracuse, from his military base in Ortygia in the

33 The myth has very ancient origins. Hesiod in Works and Days (568) and Sappho in 135 LP are the first to call the swallow the daughter of Pandion, though at this point other elements of the myth are not fixed. Aristophanes's The Birds features the nightingale Procne as a character, while Book 6 of Ovid's Metamorphoses presents the enduring Roman account of swallow Procne.

34 The naturalist William Turner (1510-68) relates the idea that the swallow's red bib represents Procne's sin. See Edwards, 'Milton's Reformed Animals', 130. In a similar vein, Christian Scandinavian legends say its breast became stained with blood because it tried to draw the thorns from Christ's head during the crucifixion.

35 Artemidorus, Oneirocritica, 2.66, cited in R White, The Interpretation of Dreams: Oneirocritica by Artemidorus (New Jersey: Noyes Press, 1975). The ominously-coloured swallow is probably an albino. See Aristotle, History of Animals, 519 6A; Aelian, On the Nature of Animals, 17.20. 
fourth century BCE. ${ }^{36}$ It was proverbial that swallows would not nest in Theban houses because Thebes was so often captured - they believed it was not safe for them to do so. ${ }^{37}$

One of the most famous swallow omens appears in Shakespeare's Antony and Cleopatra, which recounts that swallows nesting in the sails of Cleopatra's ship foretold the coming disaster at the Battle of Actium. There are two versions of this story. Cassius Dio records that Cleopatra was disturbed by the sight of swallows nesting on her ship and tent. ${ }^{38}$ On the other hand, Plutarch reports that they nested beneath the ship's stern and were attacked and driven out by other swallows. ${ }^{39}$ The latter has had some influence on cultural representations of the swallow and has occasionally been taken to mean that all swallows are ominous, but it should be understood that the circumstances, not the birds, boded ill. The Battle of Actium took place on 2 September. It would indeed be an odd and ominous swallow that made its nest around this time, since the departure of the swallows was said to take place just before 12 September. ${ }^{40}$ Only an abnormal bird would begin nesting when all the others had finished breeding and were preparing to migrate.

The swallow's departure in autumn could also symbolise disloyalty in the Roman mind. It is fitting, then, that on an autumn day Cleopatra deserted Antony in the same ship where the swallows had nested. ${ }^{41}$ As migratory birds, it makes sense that they were important in auguries related to sea travel and enterprises abroad. Some also believed they were rain birds, foretelling wet weather when they skimmed low over bodies of water and touched the surface with their wings. ${ }^{42}$

36 Aelian, On the Nature of Animals, 10.34.

37 Pliny, Natural History, 10.34.

38 Dio, Roman History, 50.15.1-2, cited in Earnest Cary and Herbert B Foster, Roman History, Volume V: Books 46-50, Loeb Classical Library 82 (Cambridge: Harvard University Press, 1917).

39 Plutarch, Antony, 60.7, cited in Bernadotte Perrin, Lives, Volume IX: Demetrius and Antony. Pyrrhus and Gaius Marius, Loeb Classical Library 101 (Cambridge, MA: Harvard University Press, 1920).

40 Pliny, Natural History, 18.311; Christopher McDonough, 'Swallows on Cleopatra's Ship', The Classical Review 96, no. 3 (2003), 258.

41 McDonough, 'Swallows on Cleopatra’s Ship', 258.

42 Theophrastus, Concerning Weather Signs, 6.15, cited in Arthur F Hort, Enquiry into Plants, Volume II: Books 6-9. On Odours. Weather Signs, Loeb Classical Library 79 (Cambridge, MA: Harvard University Press, 1916); Pliny, Natural History, 18.87; and Virgil, Georgics, 1.377, cited in H Rushton Fairclough and GP Goold, Eclogues. Georgics. Aeneid: Books 1-6, Loeb Classical Library 63 (Cambridge: Harvard University Press, 1916). 


\section{Swallows in Christian Europe}

After the fifth century CE, as Christianity emerged as the dominating force in the political and social life of Europe, the swallow's springtime arrival was explained in the Bible in the book of Jerome: 'The Stork in the Heavens knoweth her appointed times; and the turtle, and the Crane, and the Swallow observe the time of their coming. ${ }^{43}$ The association of the swallow with spring remained a major symbol in Christian Europe, but it was instead attributed to the wisdom of God. Psalm 84:3 reads: 'Yea, the sparrow hath found her a house, and the swallow a nest where she may lay her young. ${ }^{44}$ Again, references to swallows reported their presence in the household, perhaps also drawing on the ancient Roman belief that the sparrow and swallow are joint domestic familiars.

The Russian peasantry greeted the swallow in a similar manner to the ancient Rhodians, believing the bird brought warmth from paradise. Slavonians and Bohemians thought it was the bird of God, bringing light and joy to the world, and feared to bring it any harm. ${ }^{45}$ In England it was considered unlucky to kill a swallow, and lucky for a swallow to nest in the eaves. Even a cursory examination of English poetry shows the bird often nested on the outside of the house, sheltered by overhanging thatch. ${ }^{46}$

Swallows occasionally even had a positive place in the iconography of the annunciation and the nativity. ${ }^{47}$ Small birds, including the swallow, were associated with Jesus Christ due to the apocryphal gospels and the tale that the Christ Child made birds out of clay. Small birds also popularly represented the soul. ${ }^{48}$

\footnotetext{
43 Jerome 8:7 in The Holy Bible, King James Version (London: Collins, 2004).

44 Psalm 84:3 in The Holy Bible, King James Version (London: Collins, 2004).

45 William Jones, Credulities Past and Present (Piccadilly: Otto and Windus, 1880), 437.

46 Edward Armstrong, The Folklore of Birds: An Enquiry into the Origins and Distribution of Some Magico-Religious Traditions (London: Collins, 1958), 167 \& 181; S Roud and J Westwood, The Penguin Guide to the Superstitions of Britain and Ireland (London: Penguin, 2003), 445. For poetic examples, see John Clare, 'The Swallow' and 'On Seeing Two Swallows Late in October' in Selected Poems (London: Penguin, 2000); Charlotte Smith, 'The Swallow', in Beachy Head and Other Poems, ed. Charlotte Smith (London: Sold by J. Johnson, 1807).

47 H Friedmann, 'Giovanni del Biondo and the Iconography of the Annunciation', Simiolus: Netherlands Quarterly for the History of Art 3, no. 1 (1968-1969), 7ff.

48 M Dzon, 'Jesus and the Birds in Medieval Abrahamic Traditions', Traditio 66 (2011), 189-230: doi.org/10.1017/S0362152900001148.
} 
ANU Historical Journal II, Number 1

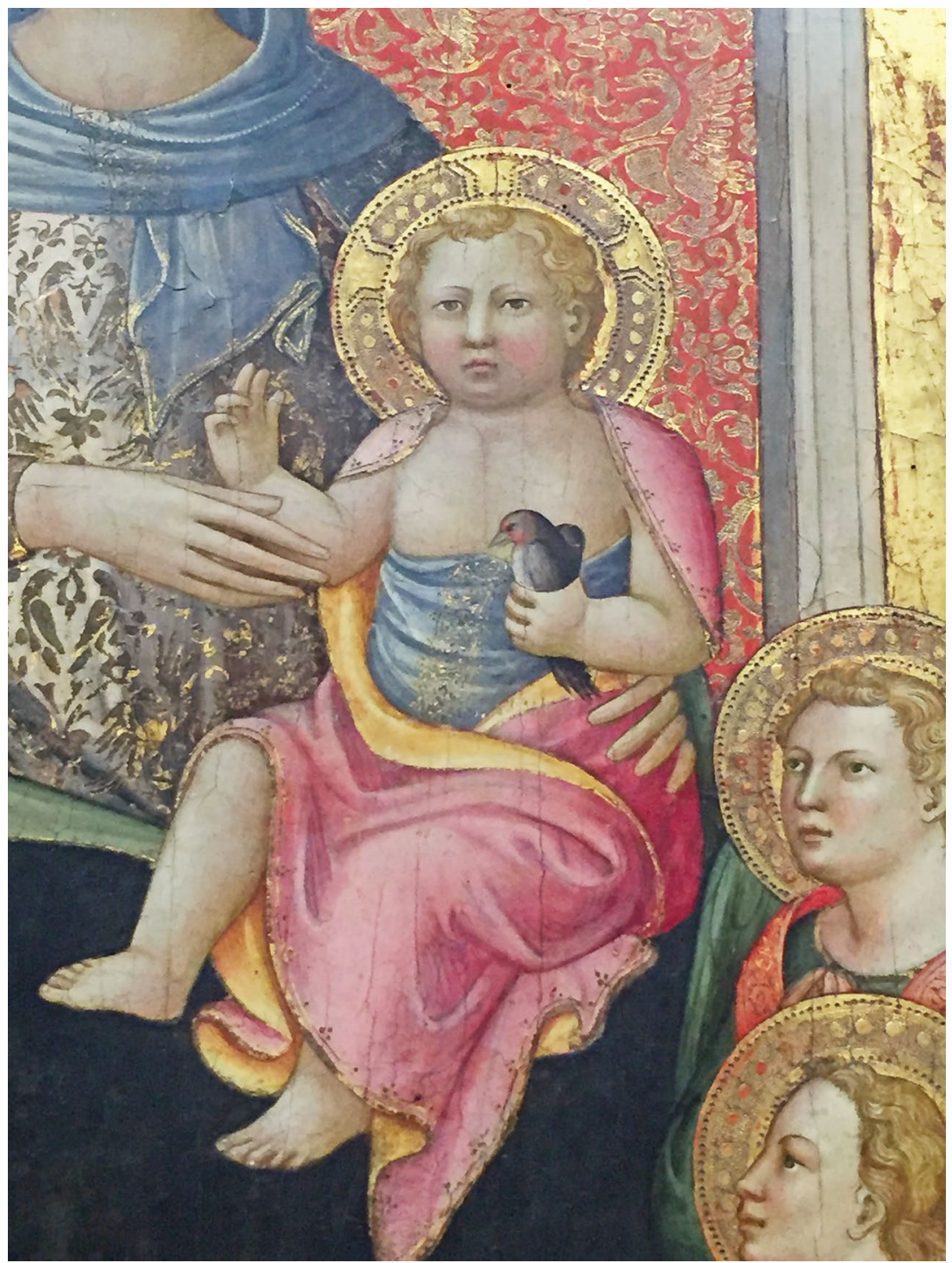

Figure 3: Detail of the Christ Child holding a swallow from Enthroned Madonna and Child with Saints Catherine of Alexandria, Francis, Zenobius and Mary Magdalene, tempera on wood panel, c. 1430-40.

Source: From the Santa Maria degli Angiolini conservatory in Florence, Italy, author's own photo. 
Gerard Legh, in Accedence of Armorie, suggested that swallows nesting on a house meant the occupant would not be made a cuckold. ${ }^{49}$ This could be a continuation of the ancient belief that swallows augured well for marriage. Dryden (1687) considered the swallow 'privileg'd above the rest / Of all the birds, as man's familiar guest'. ${ }^{50}$ In fact, attitudes to the swallow were almost 'universally positive', except in Ireland and Scotland where it was sometimes regarded as the Devil's bird. There, the protective taboo endured, but did not express respect, only fear. ${ }^{51}$

Knowledge about the swallow's ability to cross large bodies of water appears to have persisted in medieval Europe. Isidore of Seville, writing in Spain in the seventh century, records that it flies across the sea in definitive terms. ${ }^{52}$ In the early twelfth century, French monastic writer Hugh of Fouilloy made the same conclusion in his work on birds, though he was far more concerned with informing readers of how God had provided the swallow to lead men by example. The swallow, returning after the cold of winter, was compared to the righteous man in whom the cold of temptation has finally thawed..$^{53}$ German theologian Albertus Magnus (1193-1280) gives a mixed account in his encyclopaedic work On Animals. At first, he says frankly that storks depart before the swallows. Later, he reneges on this and derides common folk for believing that all birds that are not seen for a season must migrate, citing the kite and swallow as birds that hibernate. In support of this, he describes how a rotting oak cut open in Germany was found to be full of dormant swallows. ${ }^{54}$

Late medieval and early Renaissance writers tended to support the theory that swallows hibernated rather than migrated. ${ }^{55}$ Swedish writer Olaus Magnus popularised the theory of underwater hibernation in his Historia de gentibus septentrionalibus (1555), which included a woodcut illustration of fishermen drawing fish and sleeping swallows from a frozen river (Figure 4).

49 Gerard Legh, The Accedence of Armorie (London: 1597), 85.

50 Dryden, The Hind and the Panther, pt. 3, 11. 428-29.

51 Roud and Westwood, Superstitions, 446.

52 Isidore of Seville, Etymologies, 12.7.1 \& 12.7.69, cited in The Etymologies of Isidore of Seville, ed. Stephen A Barney, WJ Lewis, JA Beach and Oliver Berghof (Cambridge: Cambridge University Press, 2006).

53 Hugh of Fouilloy, Aviarium, 2.46, cited in W Clark, The Medieval Book of Birds: Hugh of Fouilloy's Aviarium (New York: Medieval and Renaissance Texts and Studies, 1992), 210-11.

54 Albertus Magnus, On Animals, 7.67-69, 87, cited in Kenneth Kitchell and Irven Michael Resnick, Albertus Magnus On Animals, vol. I (Baltimore and London: Johns Hopkins University Press), $615 \& 625$.

55 T Harrison, They Tell of Birds: Chaucer, Spenser, Milton, Drayton (Austin: University of Texas Press, 1956), 57. 


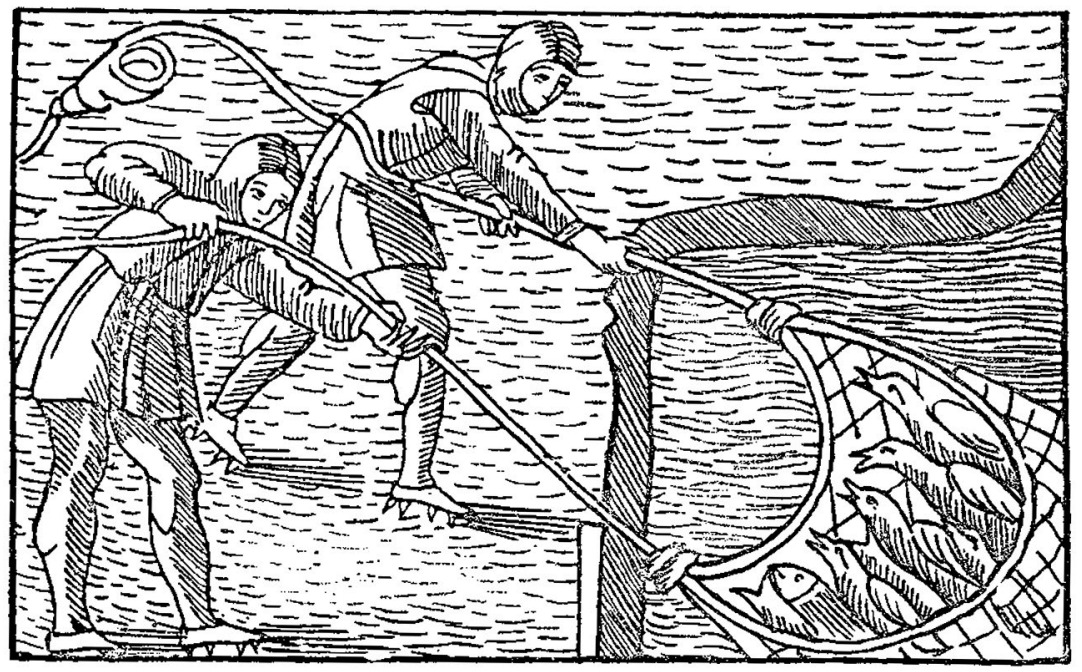

Figure 4: Fishermen drawing swallows from the ice.

Source: Reproduction taken from J. Ashton, Curious Creatures in Zoology, London, 1890.

Hibernation in the nest, meanwhile, was espoused by Swiss naturalist Conrad Gesner in De avium natura (1555). ${ }^{56}$ In the Shepheardes Calender (1579), the poet Edmund Spenser notes that the swallow heralds spring when she 'peeps out her nest'. ${ }^{57}$ Sixteenth-century naturalist William Turner expressed scepticism for the classical theory of migration to warmer climates and declined to comment on the matter. ${ }^{58}$

The earliest treatise on bird migration in Britain was written by Charles Morton in $1686 .{ }^{59}$ Here Morton laid out the scientific reasoning behind migration, but, unfortunately, instead of pointing to Africa or India, or even somewhere warm, he concluded that swallows must fly to the moon every winter. Morton calculated that the swallow's round trip to the moon would take four months, or 60 days each way. The distance

56 Conrad Gesner, De avium natura (Zurich: 1555), 529.

57 Spenser, The Shepheardes Calendar III: March, 11.

58 Harrison, They Tell, 23.

59 Charles Morton, An Enquiry into the Physical and Literal Sense of that Scripture (Jer. 8.7) ... The Stork in the Heavens knoweth her appointed times; and the turtle, and the Crane, and the Swallow observe the time of their coming', Harleian Miscellany, 12 vols (London, 1808-1811 edition: vol. 5, 498-511). The text was reprinted again in 1694, 1703 and 1739, indicating continuing interest in the idea. For commentary, see Thomas Harrison, 'Birds in the Moon', Isis 45, no. 4 (December 1954), 323: doi.org/10.1086/348354. 
from the earth to the moon was reportedly 179,712 miles, and so he estimated that swallows flew at 125 miles per hour. Since the moon requires a month to revolve around the earth, birds launching straight upwards would find the moon in the same place as when they began their journey. The inspiration for this was undoubtedly Godwin's fantasy, The Man in the Moon (1638), a fantastical story where the protagonist finds swallows and the birds of spring sojourning on the moon. He even flies thither using yoked birds. People in the seventeenth century were enchanted by the possibility of moon voyages, so this strange theory should be taken as a reflection of the new interest in the heavens following the discoveries of Copernicus, Galileo and Kepler. ${ }^{60}$

The idea of swallows undertaking lunar migration survived for a little time. Poet and dramatist John Gay in 1714 named the moon as the place 'where swallows in the winter's season keep'. ${ }^{61}$ In 1733, Alexander Pope wrote that the swallow is, 'Now in the moon, perhaps, now underground'. ${ }^{62}$ The poet Dryden mused:

But whether upward to the moon they go,

Or dream the winter out in caves below,

Or hawk at flies elsewhere, concerns us not to know. ${ }^{63}$

Interestingly enough, Dryden then purported to solve the mystery by arguing that swallows gathered on the south coast of England and flew across the Channel. Francis Willughby's Ornithology considered the question of migration vs hibernation undecided, but admitted it is more likely they fly away to warmer climes, not the moon. ${ }^{64}$

60 Harrison, 'Birds in the Moon', 323.

61 Gay, The Shepherd's Week, 'Saturday' (1714), 11.61-66.

62 Pope, Moral Essays, 'Epistle to Sir Richard Temple' (1733), 11.95-98.

63 Dryden, The Hind and the Panther, pt. 3, 11. 450-52.

64 Francis Willughby, The Ornithology of Francis Willughby (London: 1678), 212. Ornithology was first published in Latin as Ornithologiae in 1676. 
The VoYAGE to the TroRL] in the MoON.

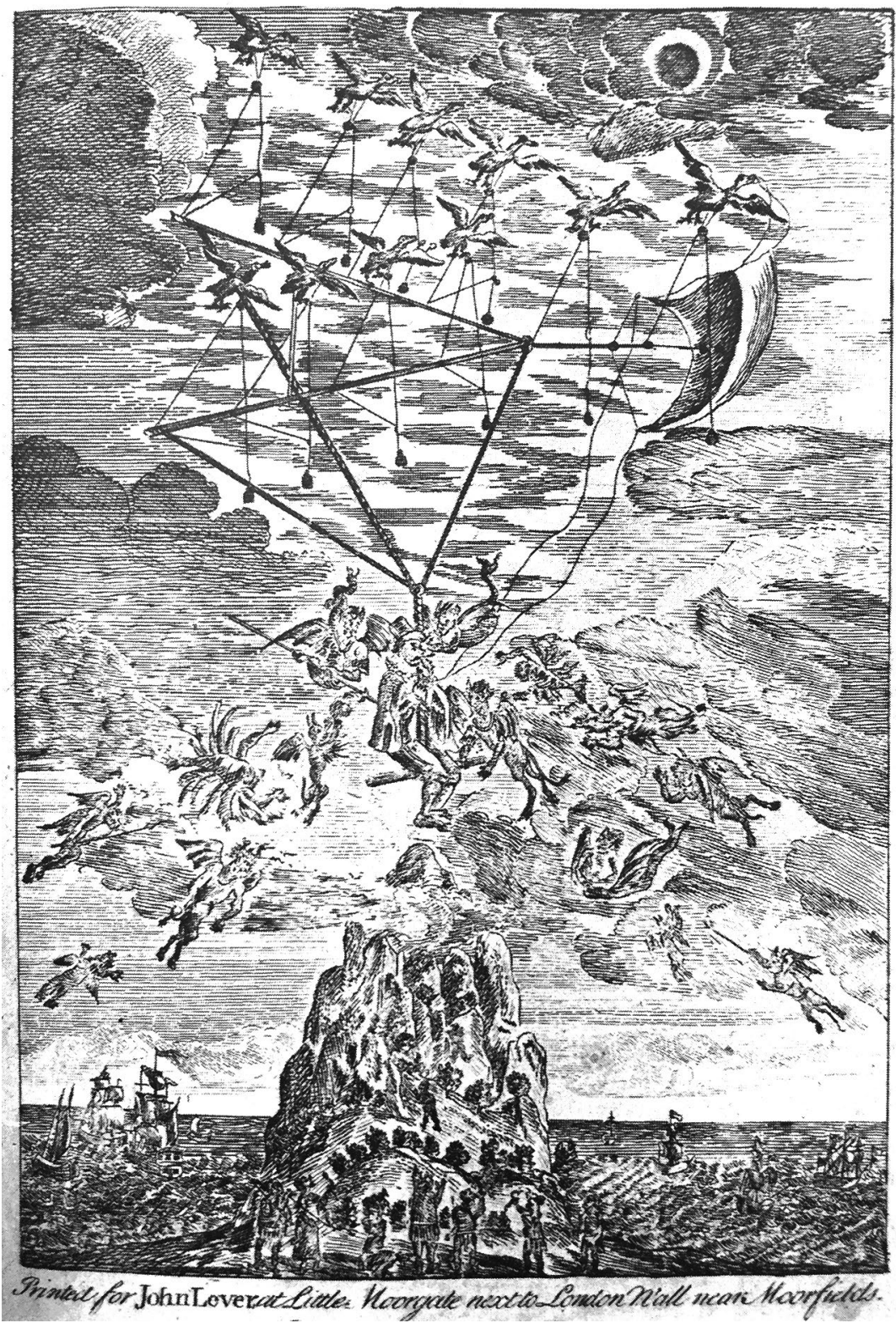

Figure 5: Frontispiece of Francis Godwin, The Strange Voyage and Adventures of Domingo Gonsales to the World in the Moon By the Several Ganzas or Large Geese.

Source: Francis Godwin, The Strange Voyage and Adventures of Domingo Gonsales to the World in the Moon By the Several Ganzas or Large Geese (London: John Lever, 1768). 
At the same time, prominent English writers such as Izaak Walton and Samuel Johnson favoured the Swedish underwater hibernation theory. Even Linnaeus, the father of modern taxonomy, subscribed to the idea. Royal Society Fellow John Hunter (1728-93) fitted an icehouse to test the hypothesis and installed a tub of water where the swallows could sleep. French naturalist George-Louis LeClerc, Comte de Buffon (1707-88), did the same. ${ }^{65}$ Meanwhile, the parson and passionate naturalist Gilbert White built an observatory on the south coast of England so he could solve the mystery of the swallow's seasonal disappearance. But instead of watching to see if they flew away, he spent his time digging up hillsides and investigating abandoned houses in search of dormant swallows. Even in the face of a complete absence of evidence in favour of hibernation, he remained unconvinced that they departed England's shores. In what may be the last letter written before his death in 1793, he wrote, 'I did not write the letter in the Gentleman's Magazine against the torpidity of swallows, nor would it be consistent with what I have sometimes asserted, so to do'. ${ }^{66}$

Yet, opinions were changing. In 1834, an article in The Dublin Penny Journal stated that their migration is now scarcely disputed by any naturalist' ${ }^{67}$ Charlotte Smith, the Gothic author and poet, wrote an exhortation to the swallow. She asked it to nest under her thatch, and though the poem shows that scientific migration was accepted by the late eighteenth and early nineteenth century, she could not help but bring up more romantic ideas of hibernation too. ${ }^{68}$ Only towards the middle and late nineteenth century do poets unequivocally agree the swallow flies to 'the sun and the south'. ${ }^{69}$

65 Elizabeth Heckendorn Cook, 'Charlotte Smith and "The Swallow": Migration and Romantic Authorship', Huntington Library Quarterly 72, no. 1 (March 2009), 56: doi.org/10.1525/hlq.2009. 72.1.48.

66 The letter is included in The Natural History and Antiquities of Selborne, 2 vols, vol. 2 (London: 1877), 302.

67 'On the Swallow and Its Habits', The Dublin Penny Journal 2, no. 104 (28 June 1834), 413-14: doi.org/10.2307/30004390.

68 Cook, 'Charlotte Smith', 50.

69 Charles Algernon Swinburne, Itylus 14 (1864). 


\section{Origin of the swallow tattoo}

The migratory patterns of the swallow also had an impact on British and, more broadly, Anglo-American sailing culture. Today, swallow tattoos are a well-recognised nautical motif-although it is striking that swallows should have been adopted as a symbol for sailors when they are not seabirds. We cannot know exactly when mariners began to ink the bird on themselves, but we know it was done throughout the nineteenth century, and probably earlier.

Some reports claim that Captain Cook's late eighteenth-century contact with Polynesia brought tattooing back to Britain, but there is ample evidence to suggest that while his discoveries sparked new interest in tattooing, it was already being practised by seamen well before this time. ${ }^{70}$ In support of this, we should note that British sailors did not adorn themselves as Polynesians did, covering swathes of skin with complex patterns. They chose small, significant icons that were derived from their own beliefs and culture instead-a heart, a crucifix, an anchor or a swallow. ${ }^{71}$ Most books that write of the swallow tattoo note the following:

For sailors [swallows] were bluebirds, heralds of home; a swallow tattoo would ensure its bearer's safe return to dry land, in the same way that an anchor symbolized hope [...] a tattooed dagger through a swallow's heart symbolizes lost love. ${ }^{72}$

Another well-known account of the swallow tattoo reports that ' $[w]$ hen a sailor had travelled 5,000 miles at sea, he earned a bluebird on the chest; with 10,000 miles, a second bird could be added on the other side'. ${ }^{73}$

As these sources reveal, swallows and bluebirds were sometimes confused with each other, both having a blue back and red breast. It is likely that although the names were used interchangeably, the bird depicted

70 Juliet Fleming, 'The Renaissance Tattoo', in Written on the Body: The Tattoo in European and American History, ed. Jane Caplan (London: Reaktion, 2000), 68. The English use of 'tattoo' is first recorded in Cook's journals: 'Both sexes paint their Bodys, Tattow [sic] as it is called in their language. This is done by inlaying the colour of Black under their skins in such a manner as to be indelible'. See 'Captain Cook's First Voyage', July 1769, Project Gutenberg, accessed at www.gutenberg.org/ files/8106/8106-h/8106-h.htm.

71 Jane Caplan, Written on the Body: The Tattoo in European and American History (London: Reaktion, 2000), xix.

72 Philip Hoare, The Sea Inside (Brooklyn: Melville House Publishing, 2015), 338.

73 Margo DeMello, Encyclopedia of Body Adornment (London: Greenwood Press, 2007), 189. 
was actually a swallow. One reference book on tattoos calls the tattoo a 'bluebird' while detailing how the bird migrates and heralds spring, behaviour that characterises the swallow and not the bluebird. ${ }^{74}$ The traditional design of the tattoo also depicts a forked tail—again, a sign of the swallow. At the very least, this imagery indicates that it was the swallow's behaviour that invited seamen to identify with it.

Of the several motivations that might underpin the decision to get a tattoo, one is magico-religious; that is, it expresses a desire for talismanic protection. ${ }^{75}$ In addition to indicating a sailor's experience, this appears to be the main function of the swallow tattoo. The common adage that one needed to travel a certain distance safely and return before he 'earned' a swallow was partly attributed to their migratory patterns and suggests the sailor wanted to imitate the bird's ability to depart across the sea and return safely every season. Yet, if we keep in mind that migration only gained currency in the mid-nineteenth century, we might say instead that they aspired towards a connection to a bird that could hibernate under the sea without drowning, or fly to the moon, the celestial body that had the power to control the tides. ${ }^{76}$

Initially, swallow tattoos seem to have been preferred almost exclusively by mariners. Other groups that practised tattooing, including convicts, were not inclined to use the symbol. For example, among Australian convicts, Simon Barnard notes that the swallow is 'noticeably absent' from the records. ${ }^{77}$ It was not until the late nineteenth and early twentieth centuries that swallow tattoos had a place in prison culture, and we get anecdotes and records of criminals and gangsters sporting 'bluebirds' on their hands. ${ }^{78}$ Someone who had served time behind bars might tattoo the bird on themselves to signify they were a 'jailbird'. Indeed, spending time in prison is still called 'doing your bird' and swallows on the fists could suggest that 'these fists fly', signalling their bearer's capabilities in a fight.

74 Jack Watkins, Tattoo Symbols and Meanings (London: Amber Books, 2010), 52.

75 Nikki Sullivan, Tattooed Bodies: Subjectivity, Textuality, Ethics and Pleasure (Connecticut: Praeger, 2001), 15.

76 The moon's effect on the sea was known since ancient times-Virgil and Pliny credit it with influence on the weather, Venerable Bede warns of how it influences the sea, and Shakespeare, in Hamlet, calls it ' $[t]$ he moist star upon whose influence Neptune's empire stands'. See ICB Dear and Peter Kemp, The Oxford Companion to Ships and the Sea (London: Oxford University Press, 2005), 371. 77 Simon Barnard, Convict Tattoos: Marked Men and Women of Australia (Melbourne: Text Publishing, 2016), 63.

78 Marc Mappen, Prohibition Gangsters: The Rise and Fall of a Bad Generation (New Jersey: Rutgers University Press, 2013), 1. 
For prisoners, the bird's migratory patterns were less important compared to their ability to symbolise freedom and swiftness. Birds in general are a potent symbol of freedom. In Victorian prisons, observers commented that prisoners loved birds and especially coveted pigeons as pets. ${ }^{79}$ When we examine the traditional design of the tattoo, it is significant that the swallow (or bluebird) is shown in flight. A flying bird evoked ideas of freedom, travel and swiftness, rather than the domesticity conjured up by the motif of the perched swallow in Roman art. In any case, the swallow's migration had an impact on the imaginations of deep sea sailors. Even if it was not understood in contemporary scientific terms, the springtime appearance of swallows still represented the hope of a safe return from a voyage.

\section{Conclusion}

By examining responses to the migration of the barn swallow, we can draw some general conclusions about the changing meanings of the swallow in Europe across the centuries. For the Greeks, it was their status as harbingers of spring, especially since their arrival heralded the start of the sailing season. The Romans showed more of a tendency to value their status as domestic familiars, sacred to household gods and shown in static poses around the house. Medieval Christian belief drew the swallow closer to God and the Christ Child and understood its migration in religious and allegorical terms, and the Renaissance debate over its migratory patterns shows how a scientific explanation for the bird's annual disappearance and reappearance suddenly became more important. The theory of lunar migration reflected how astronomical discoveries caused scientists to reconsider much of what they knew about the natural world in order to account for tantalising new possibilities. Additionally, the belief in hibernation reflected a desire to see the birds as natives rather than visitors. In the case of the Englishman Gilbert White, despite the evidence he collected that strongly supported cross-continent swallow migration, he was reluctant to accept that the swallows left the island. As White's biographer Richard Mabey states, 'he did not want them to go'. ${ }^{80}$

79 Philip Priestley, Victorian Prison Lives: English Prison Biography, 1830-1914 (London: Methuen, 1985), 47.

80 Richard Mabey, ed., Natural History of Selbourne (New York: Penguin, 1977), 210. 
Lastly, for sailors, observing the swallow's return in spring led them to adopt the bird as a symbol that could express hierarchy or talismanic protection, though the use of the swallow tattoo by prisoners shows that the bird could also be potent as a symbol of freedom and swiftness, with little regard for its migration patterns. These little birds with 'heart[s] [...] full of the spring' ${ }^{81}$ have fuelled scientific and imaginative curiosity for thousands of years, and they reveal something of the way just one aspect of an animal's natural behaviour can impact human culture and thought. 
This text is taken from ANU Historical Journal II: Number 1, published 2019 by ANU Press, The Australian National University, Canberra, Australia.

doi.org/10.22459/ANUHJII.2019.10 